\title{
Mutual repression between steroid and xenobiotic receptor and NF-kB signaling pathways links xenobiotic metabolism and inflammation
}

\author{
Changcheng Zhou, ${ }^{1}$ Michelle M. Tabb, ${ }^{1}$ Edward L. Nelson, ${ }^{2}$ Felix Grün, ${ }^{1}$ Suman Verma, ${ }^{1}$ \\ Asal Sadatrafiei, ${ }^{1}$ Min Lin, ${ }^{3}$ Shyamali Mallick, ${ }^{3}$ Barry M. Forman, ${ }^{3}$ \\ Kenneth E. Thummel, ${ }^{4}$ and Bruce Blumberg ${ }^{1}$
}

\begin{abstract}
1Department of Developmental and Cell Biology, 2Department of Medicine, and Department of Molecular Biology and Biochemistry, University of California, Irvine, Irvine, California, USA. ${ }^{3}$ Department of Gene Regulation and Drug Discovery, City of Hope National Medical Center, Beckman Research Institute, Gonda Diabetes Research Center, Duarte, California, USA. ${ }^{4}$ Department of Pharmaceutics, University of Washington, Seattle, Washington, USA.
\end{abstract}

\begin{abstract}
While it has long been known that inflammation and infection reduce expression of hepatic cytochrome P450 (CYP) genes involved in xenobiotic metabolism and that exposure to xenobiotic chemicals can impair immune function, the molecular mechanisms underlying both of these phenomena have remained largely unknown. Here we show that activation of the nuclear steroid and xenobiotic receptor (SXR) by commonly used drugs in humans inhibits the activity of NF- $\kappa B$, a key regulator of inflammation and the immune response. NF- $K B$ target genes are upregulated and small bowel inflammation is significantly increased in mice lacking the SXR ortholog pregnane $X$ receptor (PXR), thereby demonstrating a direct link between SXR and drug-mediated antagonism of NF- $\kappa B$. Interestingly, NF- $\kappa B$ activation reciprocally inhibits $S X R$ and its target genes whereas inhibition of NF- $\kappa B$ enhances SXR activity. This SXR/PXR-NF- $\kappa B$ axis provides a molecular explanation for the suppression of hepatic CYP mRNAs by inflammatory stimuli as well as the immunosuppressant effects of xenobiotics and SXR-responsive drugs. This mechanistic relationship has clinical consequences for individuals undergoing therapeutic exposure to the wide variety of drugs that are also SXR agonists.
\end{abstract}

\section{Introduction}

Rifampicin (RIF) is a macrocyclic antibiotic first used as an antituberculosis agent and now used as a component in the multidrug treatment of a wide variety of bacterial and fungal diseases (1-3). RIF therapy is complicated by its propensity to cause drug interactions by inducing hepatic drug-metabolizing enzymes such as cytochrome P450 3A4 (CYP3A4) (4). RIF also acts as an immunosuppressant to suppress humoral and cellular immunological responses in liver cells, and its immunosuppressive role has been well described in humans (5-9). Calleja et al. suggested that the immunosuppressive effects of RIF were mediated by RIF acting as a ligand for the glucocorticoid receptor (GR) (10), but this result was not replicated by other groups that showed that RIF is not a biologically significant ligand for GR $(11,12)$.

We and others have shown that RIF is a potent ligand of the orphan nuclear receptor, steroid and xenobiotic receptor (SXR) (13), also known as pregnane $X$ receptor (PXR) (14), PAR (15), and NR1I2. SXR plays a central role in the transcriptional regulation of CYP3A4 (16), which is among the most important enzymes of

Nonstandard abbreviations used: $\mathrm{CAR}$, constitutive androstane receptor; $\mathrm{Ct}$, cycle threshold; CYP, cytochrome P450; DEX, dexamethasone; GR, glucocorticoid receptor;

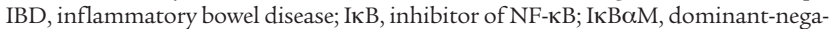
tive mutant IאB $\alpha$; PCN, pregnenolone- $16 \alpha$-carbonitrile; PXR, pregnane $\mathrm{X}$ receptor; QRT-PCR, quantitative real-time PCR; RIF, rifampicin; RU486, mifepristone; SXR, steroid and xenobiotic receptor; TPA, 12-0-tetradecanoyl-phorbol-13-acetate.

Conflict of interest: B. Blumberg is named as an inventor on 3 patents related to SXR. All other authors have declared that no conflict of interest exists.

Citation for this article: J. Clin. Invest. 116:2280-2289 (2006). doi:10.1172/JCI26283. the CYP family since it is responsible for the metabolism of more than $50 \%$ of clinically used drugs and a corresponding number of xenobiotic chemicals (17). SXR is activated by a diverse array of pharmaceutical agents, including RIF, Taxol, phenytoin, SR12813, clotrimazole, mifepristone (RU486), phenobarbital, the herbal antidepressant St. John's wort, and peptide mimetic HIV protease inhibitors such as ritonavir $(16,18,19)$. These studies indicate that SXR functions as a xenobiotic sensor (13) to coordinately regulate drug clearance in the liver and intestine via induction of genes involved in drug and xenobiotic metabolism, including oxidation (phase I), conjugation (phase II), and transport (phase III) (20). Gene knockout studies have confirmed a role for SXR in regulating the metabolism of endogenous steroids and dietary and xenobiotic compounds (21).

Although RIF activation of SXR explains its ability to induce drug-metabolizing enzymes such as CYP3A4, the mechanism through which RIF exerts immunosuppressive effects remains unclear. Interestingly, several other pharmaceutical agents such as phenytoin and RU486 also activate SXR and exert immunosuppressive side effects (22-26). On the other hand, it has also long been known that inflammation and infection reduce hepatic CYP expression (27-29), and studies have shown that proinflammatory cytokines such as IL- 1 and TNF- $\alpha$ can downregulate CYP gene expression $(29,30)$. However, the mechanisms through which inflammatory signals downregulate hepatic CYP genes are also unclear. CYP suppression has been proposed to be important for the response of organisms to physiological and pathophysiological signals (29). Although SXR is a major regulator of CYP gene expres- 

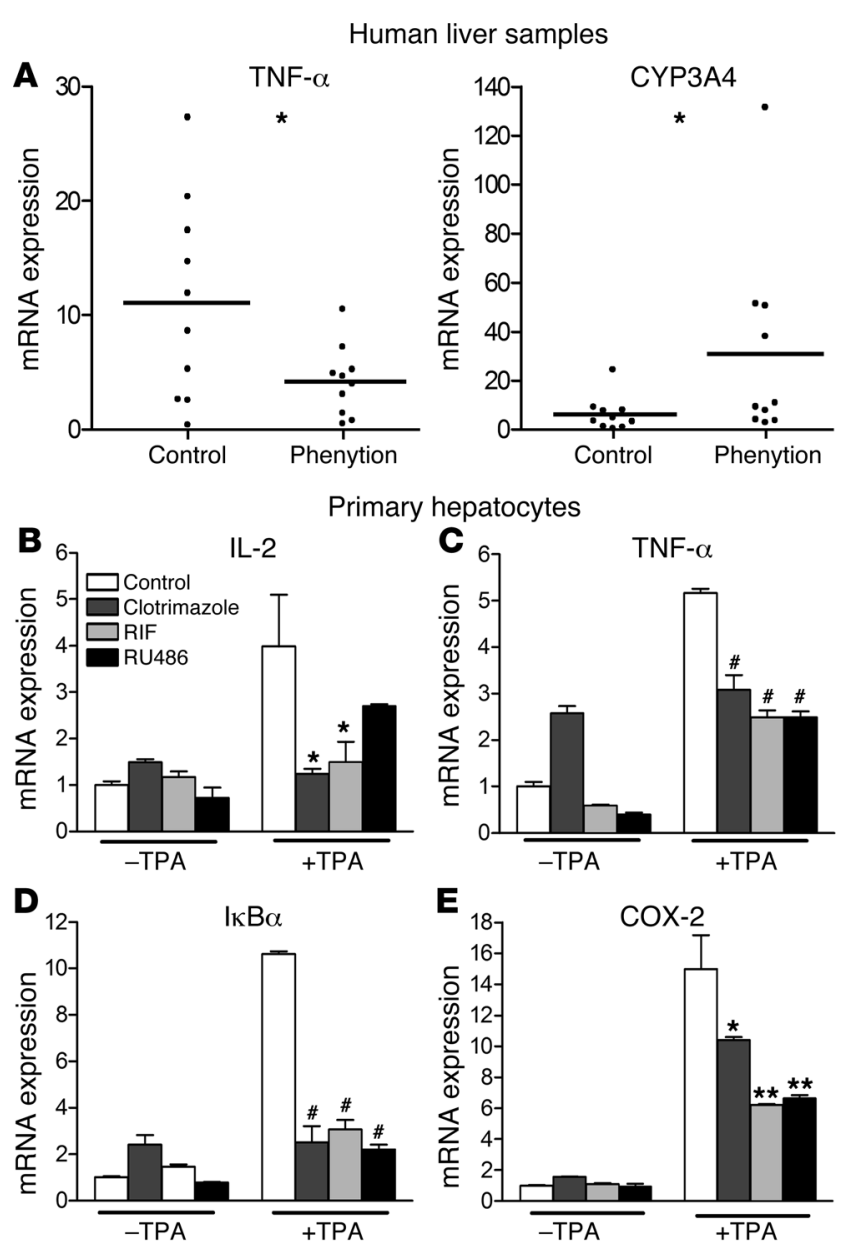

E
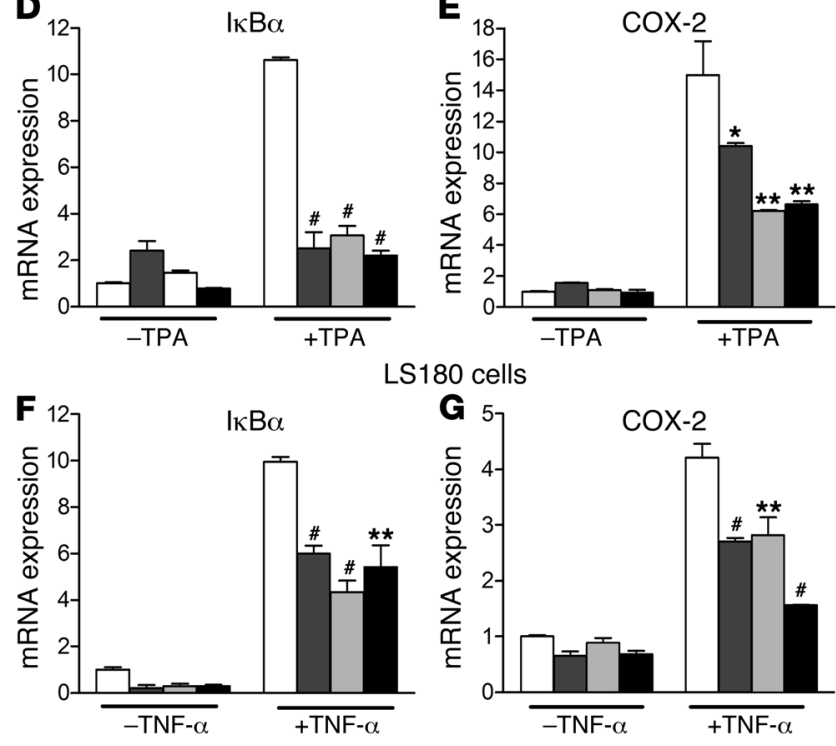

sion, its potential role in CYP suppression has not been examined compared with its well-studied roles in CYP gene induction.

Nuclear receptors can repress transcriptional responses to diverse signaling pathways, which is an essential component of their biological activities (31). For example, GR has long been known to be able to repress NF-KB signaling pathways and negatively regulate inflammatory responses $(32,33)$. This is one mechanism through which natural and synthetic GR agonists exert antiinflammatory effects in a variety of diseases (34). The NF-KB family consists of 5 members, namely p65 or Rel A, Rel B, c-Rel, p50, and p52, and is a key regulator of inflammation and the innate and adaptive immune responses (35). NF-KB normally remains in the cytoplasm bound to the inhibitory protein inhibitor of NF-KB (IKB). Activating signals, such as proinflammatory cytokines, reactive oxygen species, and viral products lead

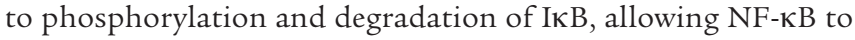

\section{Figure 1}

SXR agonists inhibit the expression of multiple NF-кB target genes. (A) Phenytoin inhibits NF-KB target genes in vivo. Human liver samples from control $(n=10)$ and phenytoin-treated group $(n=10)$ were obtained from human tissue bank, and gene expression was determined by QRT-PCR. Statistically significant expression compared with control group is marked with asterisks: ${ }^{*} P<0.05$ (Student's $t$ test). (B-E). Human primary hepatocytes and (F and $\mathbf{G})$ LS180 cells were pretreated for 18 hours with $10 \mu \mathrm{M}$ RIF, clotrimazole, or RU486 before the addition of $0.1 \mu \mathrm{M}$ TPA or $10 \mathrm{ng} / \mathrm{ml} \mathrm{TNF-} \alpha$ for 3 hours, as indicated. Total RNAs were isolated, and the expression of NF-KB target genes was determined by QRT-PCR assays. $n=3 .{ }^{* *} P<0.01 ;{ }^{\#} P<0.001$.

translocate to the nucleus and directly regulate the expression of its target genes (36). Functional crosstalk between NF-KB and several other steroid receptors (e.g., estrogen receptor, progesterone receptor, and androgen receptor) has been demonstrated and suggested to have physiological significance (34).

Here we report that activation of SXR by RIF and other agonists antagonizes the activity of NF- $\mathrm{\kappa B}$ in vitro and in vivo. SXR inhibits NF-KB-mediated reporter activity as well as the expression of NF-KB target genes. Mice deficient in the SXR ortholog PXR show increased expression of NF- $\mathrm{KB}$ target genes in multiple tissues associated with increased intestinal inflammation. Not only

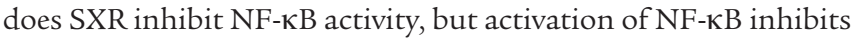
SXR activity and the expression of SXR target genes. Inhibition of NF- $\mathrm{KB}$ also enhances the activity of SXR and the expression of its target genes. Thus, the negative crosstalk between SXR and NF- $\mathrm{KB}$ not only reveals the possible mechanism underlying the immunosuppressive effects of RIF but also explains the well-recognized decreased expression of hepatic CYP genes during inflammation or infection. These observations reveal SXR's novel function as a negative mediator of inflammation and immunity and suggest an important relationship between drug and xenobiotic metabolism and the immune system or immunologic responses. Therefore, our results provide critical mechanistic insights for effectively treating an increasing number of infectious diseases and understanding physiologic effects of select "alternative medicines." They may also have direct clinical consequence for treatment of immunocompromised patients and help us to understand homeostatic mechanisms involving inflammation and metabolism.

\section{Results}

SXR agonists inbibit NF-אB-regulated proinflammatory genes. Several commonly used clinical drugs including RIF are able to activate SXR and induce CYP3A4 expression. For example, phenytoin, a widely used anticonvulsant drug, exhibits efficacious induction of liver CYP3A4 enzyme by activation of SXR (19). Interestingly, phenytoin therapy has common immunosuppressive side effects, and phenytoin has also been used to treat a variety of inflammatory diseases such as rheumatoid arthritis $(22-24,37)$. To test whether activation of SXR has effects on inflammation, liver samples collected from 10 donors who had undergone phenytoin therapy of varying duration were analyzed for expression of mRNA encoding the major proinflammatory cytokine TNF- $\alpha$. In accord with the reported antiinflammatory effects of phenytoin, TNF- $\alpha$ mRNA expression was significantly lower in the livers of donors taking phenytoin (Figure 1A). Phenytoin also significantly induced the SXR target gene CYP3A4 in the same liver samples. Although it has been shown that phenytoin can activate another nuclear receptor 

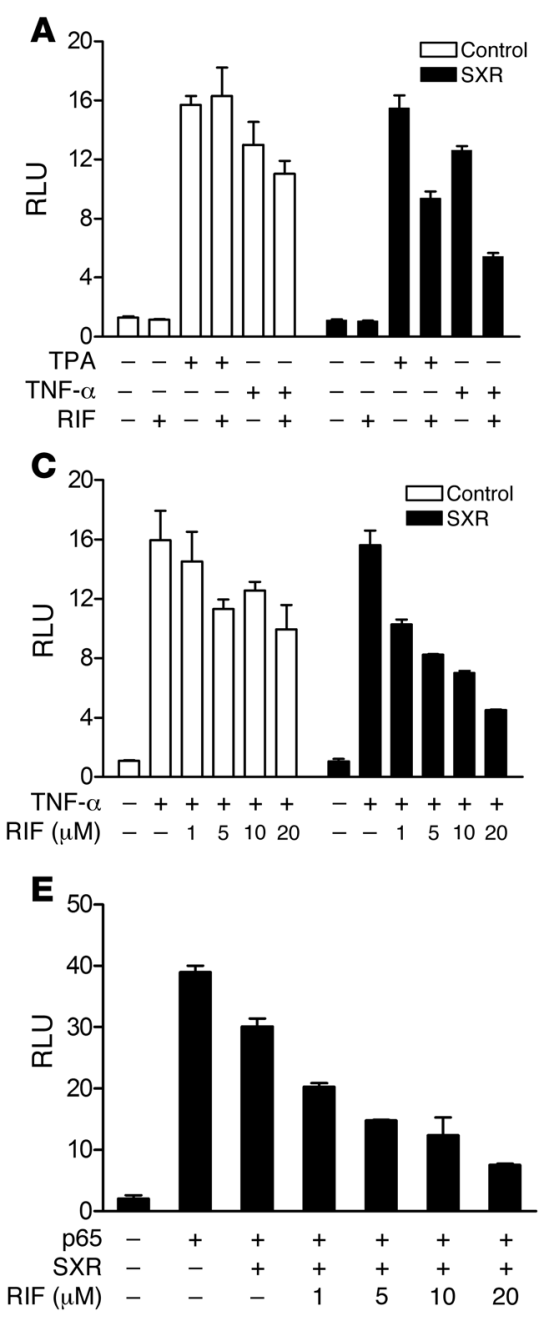
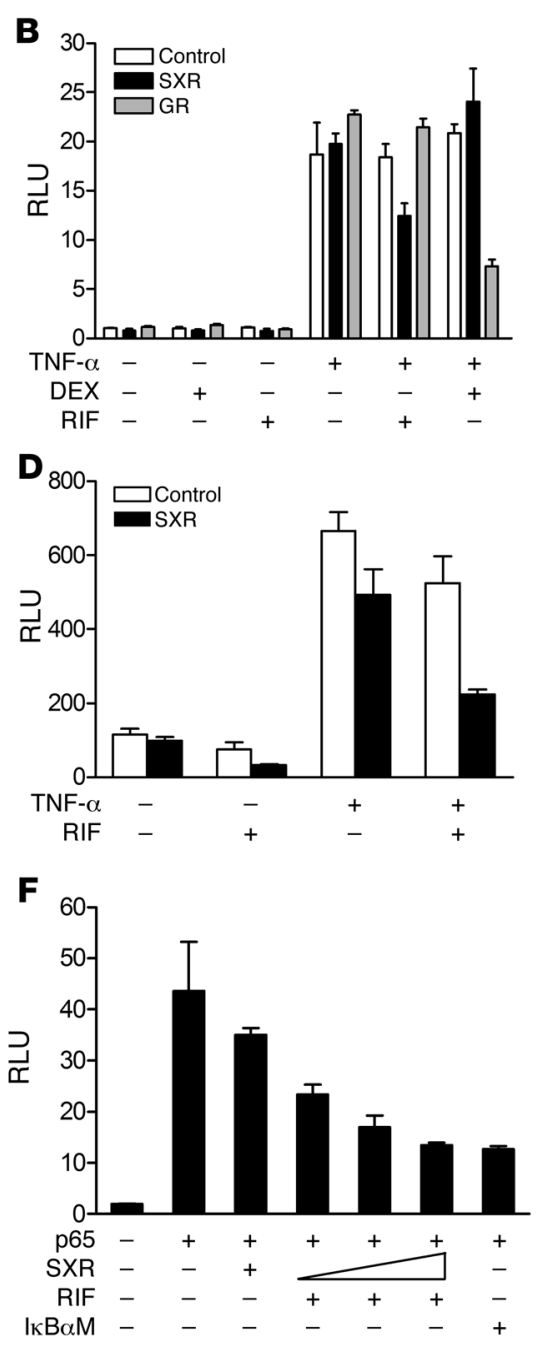

\section{Figure 2}

RIF represses NF-kB-dependent transcription in an SXR-dependent manner. (A) RIF represses TPA- and TNF- $\alpha$-induced NF- $\kappa B-$ dependent transcription in the presence of SXR. (B) Repression of NF- $\mathrm{KB}$ by RIF is not mediated by GR but by SXR. (C) Dose-dependent inhibition of NF- $\kappa B$ activity by RIF in the presence of SXR. HepG2 cells were cotransfected with an NF-KB-dependent reporter

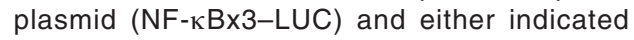
expression plasmid or control DNA. Cells were cotreated with TPA $(0.1 \mu \mathrm{M})$ or TNF- $\alpha(10 \mathrm{ng} / \mathrm{ml})$ in the absence or presence of RIF $(10 \mu \mathrm{M})$ or DEX (0.1 nM). (D) SXR antagonizes the action of NF-kB on the COX-2 promoter. Cells were transfected with COX-2 promoter (COX-2-LUC) along with SXR expression vector or control vector. Transfected cells were treated with DMSO or RIF $(10 \mu \mathrm{M})$ and $10 \mathrm{ng} / \mathrm{ml}$ TNF- $\alpha$. (E) Dose-dependent inhibition of p65 activity by RIF in the presence of SXR. HepG2 cells were transfected with NF-кB reporter along with the indicated vectors. Cells were treated with TPA $(0.1 \mathrm{nM})$ or RIF at the indicated concentrations 24 hours before the assay. (F) HepG2 cells were transfected with increasing amounts of SXR at $0.5: 1,1: 1$, or 2:1 ratios with p65 expression vector. The mutant form $I_{\kappa} B \alpha\left(I_{\kappa} B \alpha M\right)$ vector was used at 1:1 ratio with p65 expression vector. HepG2 cells were cotransfected with NF-KB reporter, p65 expression vector, and either control DNA or SXR expression vector. Cells were treated with RIF at $10 \mu \mathrm{M}$ for 24 hours as indicated before the assay.
- constitutive androstane receptor (CAR) (38), it's unlikely that CAR is involved in phenytoin-mediated CYP3A4 induction since CAR only exhibits very weak binding and functional activation of the CYP3A4 promoter and has pronounced selectivity for CYP2B6 over CYP3A4 (39). Nevertheless, these experiments cannot exclude the possible involvement of CAR in TNF- $\alpha$ inhibition.

The GR and several other nuclear receptors have been shown to interact with the NF-кB pathway and exhibit antiinflammatory effects (34). Considering that RIF is a strong activator of SXR, but not other nuclear receptors, and that another SXR agonist, phenytoin, can inhibit the NF- $\mathrm{kB}$ target gene TNF- $\alpha$, we hypothesized that the immunosuppressive effects of RIF and other SXR agonists are mediated by interference with NF- $\mathrm{KB}$. We tested the ability of SXR to antagonize NF- $\mathrm{KB}$ signaling by analyzing the expression of NF- $\kappa \mathrm{B}$ target genes in response to SXR activators in 2 cell types where SXR is abundant: human primary hepatocytes and intestinal LS180 cells. Cells were pretreated with $10 \mu \mathrm{M}$ of the SXR agonists, clotrimazole, RIF, or RU486 for 18 hours before stimulation for 3 hours with either $100 \mathrm{nM}$ 12-0-tetradecanoyl-phorbol-13-acetate (TPA) or $10 \mathrm{ng} / \mathrm{ml}$ TNF- $\alpha$. Quantitative real-time PCR (QRT-PCR) analysis showed that TPA and TNF- $\alpha$ induced expression of the NF- $\kappa \mathrm{B}$ target genes IL-2, COX-2, I $\mathrm{B} \alpha$, and TNF- $\alpha$ in primary hepatocytes (Figure 1, B-E) and LS180 cells (Figure 1, F and G). All
3 of the SXR agonists tested blunted the stimulation of NF- $\mathrm{KB}$ target gene expression by NF- $\mathrm{KB}$ activators in both cell lines (Figure $1, B-G$ ), confirming and extending the phenytoin result (Figure 1A). In accord with these results, activation of mouse PXR by pregnenolone-16 $\alpha$-carbonitrile (PCN) in primary mouse hepatocytes also significantly inhibited TNF- $\alpha$-induced NF- $\kappa$ B target gene expression (Supplemental Figure 1; supplemental material available online with this article; doi:10.1172/JCI26283DS1).

Pharmacokinetic studies have shown that the plasma levels of RIF can reach micromolar concentration, and it has been well documented that administration of RIF significantly induces CYP3A4 expression in the liver and intestine $(4,40)$. Therefore, the concentration used to treat cells is physiologically relevant and would be expected to elicit the same results in vivo. We note that clotrimazole treatment slightly enhanced expression of NF-кB target genes in primary hepatocytes (Figure 1, B-E) but not in LS180 cells (Figure 1, F and G). This unexpected induction may result from cell type- or ligand-specific effects or could reflect the activity of non-SXR-dependent pathways. Four different human or mouse SXR/PXR ligands all lead to substantial and significant

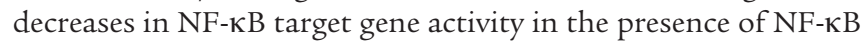
activators. This indicates that activation of SXR indeed can inhibit NF-кB-mediated gene expression. 
A

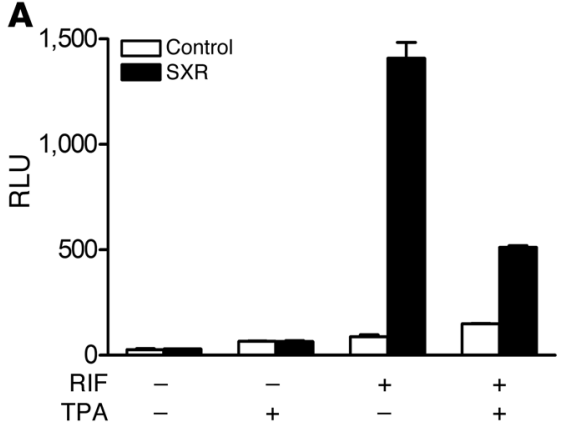

C

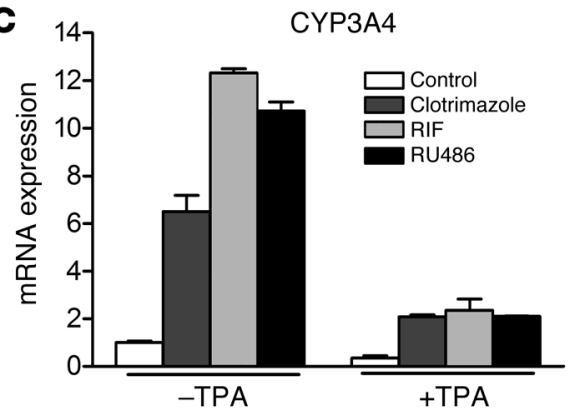

E

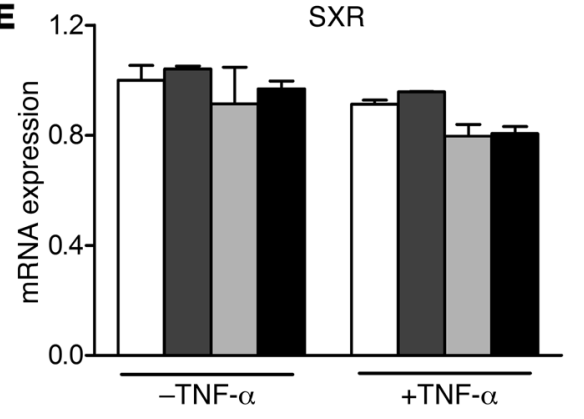

B $1,7507 \square$ control

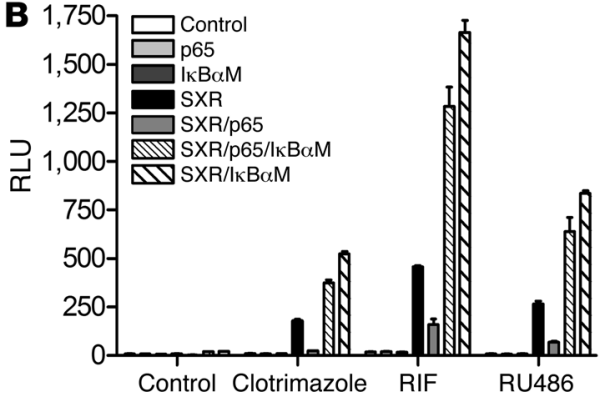

D

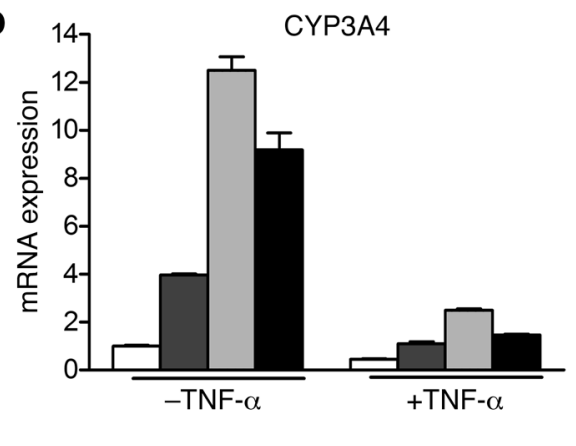

$\mathbf{F}$

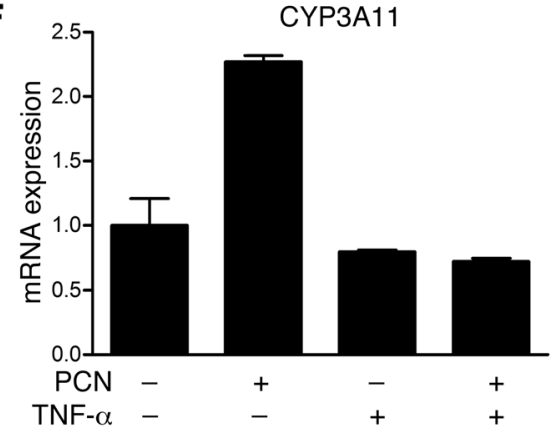

Figure 3

Activation of NF- $\mathrm{KB}$ antagonizes SXR signaling and inhibits expression of the SXR target gene CYP3A4. (A) HepG2 cells were transfected with SXR-dependent reporter (XREM-LUC) with control or SXR expression vectors. Cells were treated with $10 \mu \mathrm{M}$ RIF in the presence or absence of TPA $(0.1 \mu \mathrm{M})$. (B) p65 inhibits SXR transactivation and $\mathrm{I}_{\mathrm{K}} \mathrm{B} \alpha \mathrm{M}$ rescues p65-mediated inhibition of SXR-dependent reporter gene activation. p65 or I $\mathrm{B} \alpha \mathrm{M}$ was used at a 1:1 ratio with SXR expression vector. After transfection, cells were treated with $10 \mu \mathrm{M}$ RIF, clotrimazole, or RU486 for 24 hours before the assay. (C) Human primary hepatocytes and (D and E) LS180 cells were treated for 24 hours with $10 \mu \mathrm{M}$ RIF, clotrimazole, or RU486 in the presence or absence of $0.1 \mu \mathrm{M}$ TPA or $10 \mathrm{ng} / \mathrm{ml}$ TNF- $\alpha$, as indicated. (F) Mouse primary hepatocytes were treated for 24 hours with $10 \mu \mathrm{M}$ PCN in the presence or absence of $10 \mathrm{ng} / \mathrm{ml}$ mouse TNF- $\alpha$. Total RNAs were isolated, and expression of human CYP3A4 and SXR genes as well as mouse CYP3A11 gene was determined by QRT-PCR assays.
RIF inbibits NF-KB activity in an SXR-dependent manner. Since SXR agonists such as RIF inhibit NF- $\mathrm{KB}$ target gene expression, we next tested whether RIF inhibited NF- $\kappa$ B activity in an SXR-dependent manner. The effects of RIF on regulation of NF- $\mathrm{BB}$ reporter activity were determined in HepG2 liver cells transfected with an NF-кB reporter in the presence or absence of SXR expression plasmid. Treatment with known NF- $\kappa$ B pathway activators such as TPA or TNF- $\alpha$ resulted in a marked increase in NF- $\kappa B$ reporter activity (Figure 2A). NF-кB activity was inhibited by RIF in the presence of SXR, but RIF treatment had no significant effect on NF- $\kappa B$ activity in the absence of the SXR expression vector. Consistent with

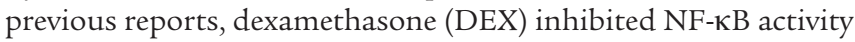
when GR was overexpressed whereas RIF treatment only inhibited NF- $\mathrm{BB}$ activity when SXR was overexpressed (Figure $2 \mathrm{~B}$ ). This suggests that RIF is not acting as a ligand for GR, but rather as an SXR-specific ligand. We confirmed this point in separate GR cotransfection experiments (Supplemental Figure 2). RIF inhibition of NF-кB activity was dose dependent in the presence of SXR (Figure 2C). The constitutively active VP16-SXR was also able to inhibit NF- $\mathrm{KB}$ reporter activity while the VP16 activation domain alone had no effect on NF-אB activity (Supplemental Figure 3). Taken together, these data indicate that repression of NF- $\kappa$ B by RIF is mediated by SXR and not by GR.
The COX-2 promoter contains an NF- $\mathrm{KB}$-binding site that is required for maximal response to TNF- $\alpha$. We used a reporter construct containing this promoter to analyze the effect of RIF on NF- $\mathrm{KB}$ activity and to confirm the above findings from a synthetic $\mathrm{NF}-\kappa \mathrm{B}$ reporter in a naturally occurring promoter. Consistent with the results using the NF- $\mathrm{KB}$ reporter, HepG2 cells transfected with the COX-2 reporter and treated with RIF showed inhibition of COX-2 reporter activity in an SXR-dependent manner (Figure 2D). We infer that activation of SXR is able to antagonize NF-кB signaling and inhibit expression of its target genes.

To eliminate the possibility that the compounds were affecting other pathways, we activated the NF- $\mathrm{KB}$ reporter by overexpressing $\mathrm{p} 65$ (RelA) protein, which is primarily responsible for NF- $\mathrm{B}$ transactivation. As expected, $\mathrm{p} 65$ activated the NF- $\mathrm{\kappa B}$ reporter and RIF inhibited this activation in a concentration-dependent manner (Figure 2E). Interestingly, SXR inhibited p65 activity in the absence of added ligand, and RIF further enhanced this repression mediated by SXR. The observed inhibition was also proportional to the ratio of SXR to p65 expression vectors. When cells were transfected with SXR and p65 expression vector in a 2:1 molar ratio, the ability of SXR to repress NF- $\mathrm{KB}$ activity was comparable

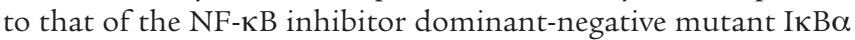
(IкB $\alpha \mathrm{M})$ (Figure 2F). 

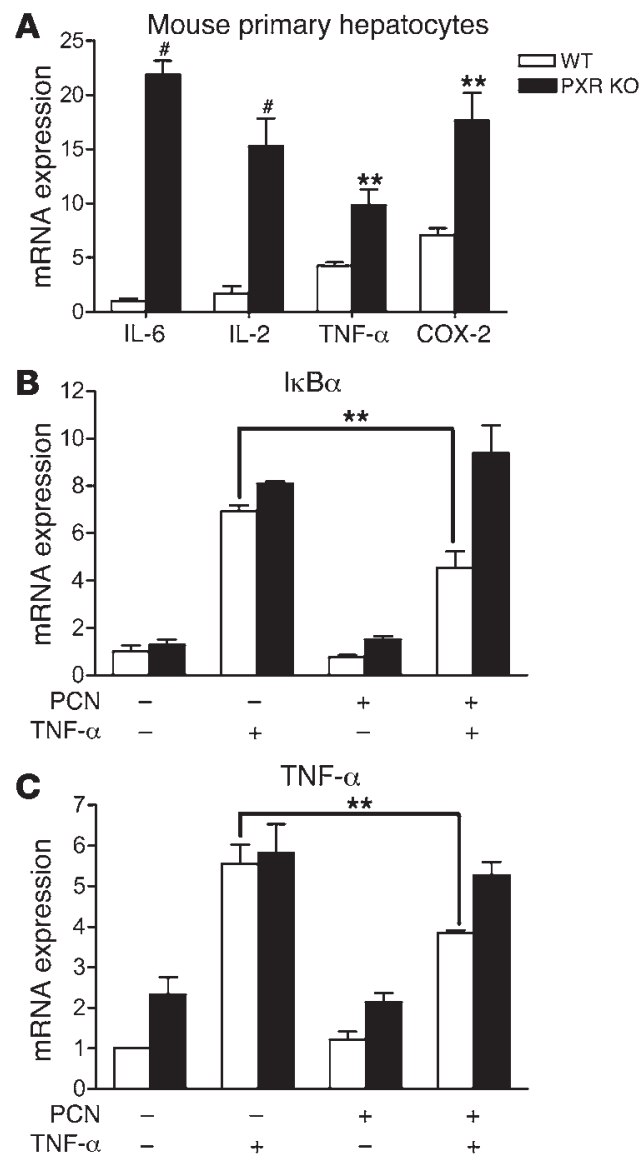

Activation of NF- $\kappa B$ antagonizes SXR signaling in buman and mouse cells. It has long been known that expression of hepatic CYP genes is decreased during infections or by inflammatory stimuli (27). Compared with our knowledge of CYP induction, the mechanisms for CYP suppression are poorly understood (29). Since SXR is a major regulator for several CYP genes and NF- $\mathrm{KB}$ is the central transcriptional regulator of the immune and inflammatory responses, we hypothesized that activation of NF- $\mathrm{\kappa B}$ could inhibit SXR activity. SXR reporter activity was induced by RIF, and this induction was reduced by addition of the NF-KB inducer TPA (Figure 3A). Similarly, expression of $\mathrm{p} 65$ strongly repressed RIF-induced SXR reporter activity (Figure $3 \mathrm{~B})$. On the other hand, overexpression

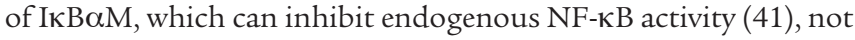
only rescued p65-mediated repression of SXR but also enhanced both basal and activated SXR activity (Figure $3 \mathrm{~B}$ ). This suggests that SXR activity is normally inhibited by NF- $\kappa B$ in vivo and that

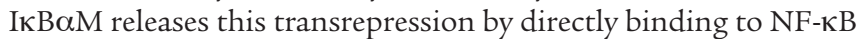

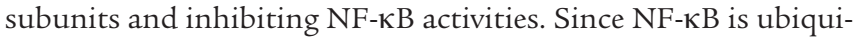
tously expressed, repression of SXR by NF- $\kappa \mathrm{B}$ may be relevant in tissues other than liver and intestine where SXR is abundant. Such tissues include kidney, lung, bone, and normal and neoplastic breast tissues where SXR is expressed at lower but detectable levels and where SXR function remains to be elucidated $(42,43)$.

We next tested whether NF- $\kappa \mathrm{B}$ activation affected the expression of the SXR target gene CYP3A4 in human primary hepatocytes and intestinal LS180 cells. Treatment with either TPA or TNF- $\alpha$ almost completely blocked the induction of CYP3A4 mRNA by SXR (Figure 3, C and D). SXR expression was not significantly

\section{Figure 4}

PCN inhibits TNF- $\alpha$-induced NF- $\kappa B$ target gene expression in WT primary hepatocytes but not in PXR knockout primary hepatocytes. (A) Mouse primary hepatocytes were isolated from WT or PXR knockout mice. Total RNAs were isolated and expression of NF-kB target genes was determined by QRT-PCR. (B and C) Mouse primary hepatocytes were pretreated for 18 hours with $10 \mu \mathrm{M}$ PCN before the addition of $10 \mathrm{ng} / \mathrm{ml}$ mouse TNF- $\alpha$ and incubation for 3 hours. Total RNAs were

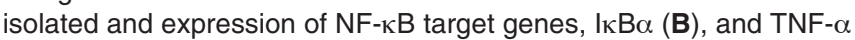
(C) was determined by QRT-PCR. $n=3 .{ }^{* \star} P<0.01$; ${ }^{\sharp} P<0.001$.

changed by TNF- $\alpha$ treatment, suggesting that the inhibition of CYP3A4 expression is not related to changes in SXR levels (Figure $3 \mathrm{E})$. Furthermore, mouse primary hepatocytes were also isolated and treated with the mouse PXR ligand PCN in the presence or absence of $10 \mathrm{ng} / \mathrm{ml}$ of mouse TNF- $\alpha$. As expected, PCN significantly induced CYP3A11 expression. Similar to the results obtained in human cell lines, this induction was abolished when the cells were treated with $10 \mathrm{ng} / \mathrm{ml}$ mouse TNF- $\alpha$ (Figure 3F). Last, inhibition of endogenous NF- $\kappa \mathrm{B}$ activity by cotransfection of IאB $\alpha M$ enhanced the ability of VP16-SXR to induce expression of CYP3A4 in LS180 cells (Supplemental Figure 4). This is consistent with our transfection results showing that IкB $\alpha$ M enhanced SXRmediated reporter activity (Figure $3 \mathrm{~B}$ ). We infer that NF- $\kappa \mathrm{B}$ can antagonize SXR signaling, establishing that the crosstalk between SXR and NF-кB can be bidirectional.

Activation of PXR inbibits NF- $\mathrm{B} B$ signaling in vivo, and $N F-\kappa B$ target gene expression is upregulated in PXR knockout mice. If there is a biologically relevant, mutually inhibitory interaction between SXR and NF- $\mathrm{B}$, one would expect this to be reflected in tissues from knockout animals. To test this, we first prepared primary hepatocytes from WT and PXR knockout mice and evaluated the expression of NF-אB target genes, particularly some proinflammatory cytokines, by QRT-PCR. The expression levels of those cytokines were low compared with that of CYP3A11 (cycle threshold $[\mathrm{Ct}]=\sim 20$ ), but they were all readily detectable by QRT-PCR (IL-6, Ct $=\sim 29$; IL-2, $\mathrm{Ct}=\sim 27$; $\mathrm{TNF}-\alpha, \mathrm{Ct}=\sim 27$; $\mathrm{COX}, \mathrm{Ct}=\sim 26$ ). Interestingly, the proinflammatory cytokines, including IL-6, IL-2, TNF- $\alpha$, and COX-2, were elevated in primary hepatocytes of $\mathrm{PXR}^{-/-}$compared with WT mice (Figure 4A). These results would be expected if endogenous PXR normally restricts the activity of NF-KB in WT mice. Furthermore, consistent with the results obtained in human primary hepatocytes and LS180 cells, induction of the NF- $\mathrm{KB}$ target genes, I $\mathrm{B} \alpha$ and TNF- $\alpha$, by TNF- $\alpha$ was significantly inhibited by 24 -hour PCN treatment in hepatocytes isolated from WT mice. However, in hepatocytes isolated from $\mathrm{PXR}^{-/-}$mice, $\mathrm{PCN}$ had no effect on mouse TNF- $\alpha$-induced TNF- $\alpha$ and IкB $\alpha$ gene expression (Figure $4, \mathrm{~B}$ and $\mathrm{C}$ ). This further suggests that repression of NF- $\mathrm{\kappa B}$ target gene by PCN is mediated by the PXR signaling pathway.

We next tested the ability of the PXR signaling pathway to inhibit NF-kB-dependent gene expression in vivo. WT and $\mathrm{PXR}^{-/-}$mice were injected intraperitoneally with the PXR ligand PCN for 3 consecutive days, and total RNAs were isolated from PXR-abundant tissues - liver and intestine. PXR and NF- $\mathrm{B}$ target genes were analyzed by QRT-PCR. As expected, PCN treatment significantly induced PXR target gene CYP3A11 in both liver and intestine of WT mice but not $\mathrm{PXR}^{-/-}$mice (Figure 5A). Consistent with the results obtained in primary hepatocytes, loss of PXR resulted in exhibition of elevated expression of NF- $\mathrm{KB}$ target genes in the liver and intestine (Figure 5B). The elevated levels of NF- $\mathrm{KB}$ target genes 
A

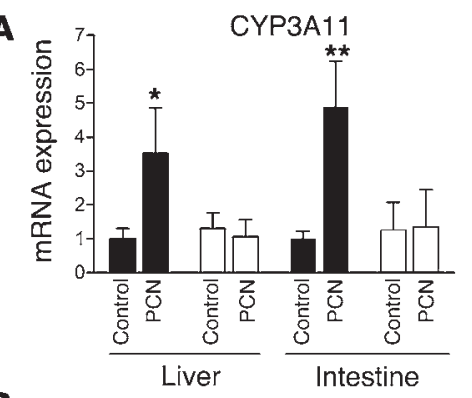

B
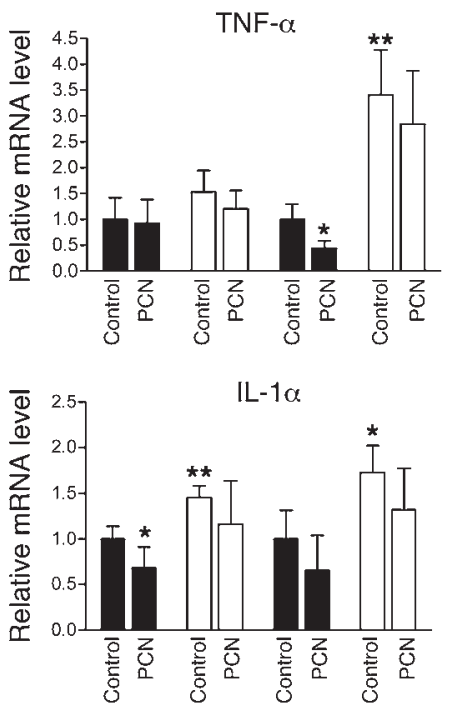

IL-15

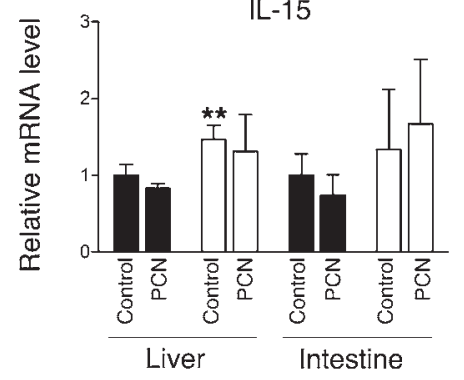

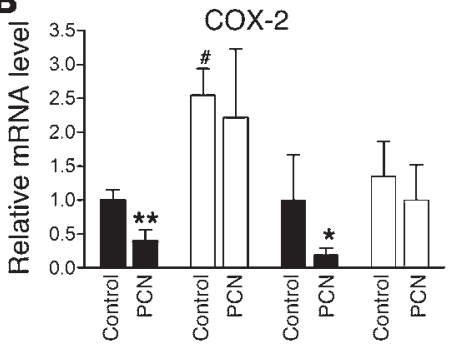

- $W T$

$\square$ PXR KO

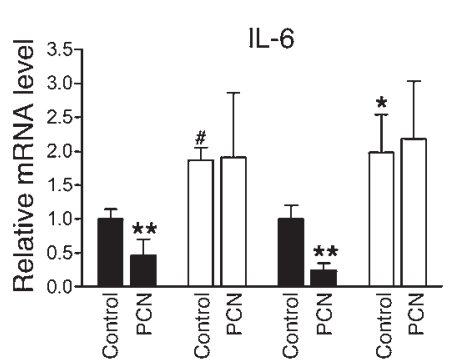

IL-2
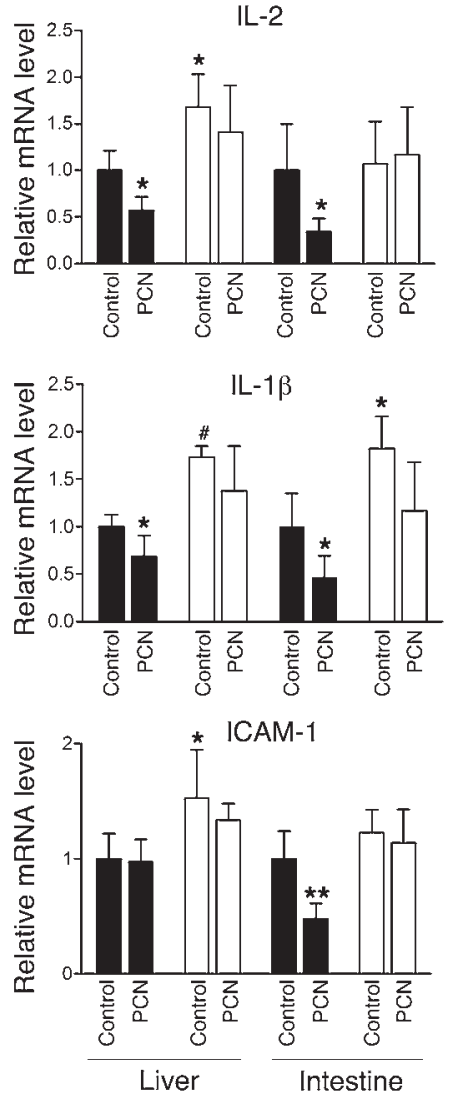

Figure 5

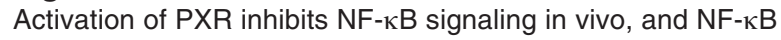
target gene expression is upregulated in PXR knockout mice. Ten-week-old male PXR ${ }^{-1-}$ and C57BL6/J (WT) mice (4 per group) were injected intraperitoneally with either the PXR ligand PCN $(50 \mathrm{mg} / \mathrm{kg}$ ) or vehicle control (DMSO) for 3 consecutive days. Liver and intestine tissues were collected, and total RNAs were isolated. Expression of CYP3A11 (A) and multiple NF-אB target genes (B) in WT or $\mathrm{PXR}^{-1-}$ mice was determined by QRT-PCR. Statistically significant expression compared with WT control group is marked with asterisks. ${ }^{*} P<0.05$; ${ }^{* \star} P<0.01$; and ${ }^{\#} P<0.001$.

genes in PXR-/- mice. These results suggest that PXR/SXR is able to negatively regulate NF- $\mathrm{KB}$ activity in vivo and loss of PXR resulted in increased expression of NF-KB target genes. Our data are also consistent with a recent report showing that production of the proinflammatory cytokines TNF- $\alpha$ and IL-1 $\beta$ is significantly inhibited in RIF-treated human mononuclear cells (44).

Small bowel inflammation in PXR knockout mice. The gene expression profiles from $\mathrm{PXR}^{-1}$ and WT mice suggested that $\mathrm{PXR}^{-1}$-animals would have a more proinflammatory stance that would be directly reflected in the tissues with normal high-level PXR expression. Histological examination of the various tissues of WT and $\mathrm{PXR}^{-1-}$ animals demonstrated a marked difference in the small intestine (Figure 6, A and B, and Supplemental Figure 5) and confirmed the previously reported absence of histological differences in other major tissues (45). Multiple tissues from PXR-deficient and WT mice, ranging from 12 to 16 weeks of age, were evaluated. The jejunal tissues in all $5 \mathrm{PXR}^{-1-}$ mice demonstrated an increase in the depth of the intervillous crypts and a marked mononuclear cell inflammatory infiltrate restricted to the mucosa (Figure 6B). Notably, we did not identify crypt abscesses, granulomata, definitive villous blunting, or evidence of vasculopathy. The bowel inflammation in PXR knockout mice cannot be explained by infection with Helicobacter, a common bacterial contaminant found in many animal facilities. We tested intestines isolated from both WT and PXR $-/-$ mice and found that both were infected with Helicobacter as measured by PCR (data not shown). Moreover, no alteration was observed in the expression of multidrug resistance gene 1a (MDR1a) in intestine or liver of the PXR-- animals $(46,47)$ (data not shown), suggesting that the inflammation probably does not result from loss of MDR1a expression as has been reported in the MDR1a knockout model (48). The inflammatory infiltrate is associated with more prominent epithelial nuclear atypia and an increased fragility to the villous epithelium. In contrast to the small bowel, there were no histological changes evident are statistically significant but not as high as those in primary hepatocytes, which may reflect cell type specificity of differences in the whole animal compared with isolated hepatocytes. Some of those proinflammatory genes, such as IL-6, IL- $1 \beta$, and IL- $1 \alpha$, were elevated in both liver and intestine of $\mathrm{PXR}^{-/}$mice whereas others, such as IL-2, IL-15, and ICAM-1, were only upregulated in liver, which may be due to the tissue-type specific effects. Furthermore, PCN treatment can inhibit the expression of most NF- $\mathrm{KB}$ target genes tested in WT mice but had no significant effect on those in the colon of $\mathrm{PXR}^{-/-}$mice. It was recently reported that genetic variation in the SXR gene, associated with altered activity of SXR, is also strongly correlated with susceptibility to inflammatory bowel diseases (IBDs), including Crohn disease and ulcerative colitis (49). SXR expression is downregulated in the gut of IBD patients (50). These reports suggest that dysregulation of SXR expression or activity may contribute to the pathophysiology of these diseases. Taken together with the results from human cells above (Figure 4), our observations suggest that SXR/PXR may normally function 

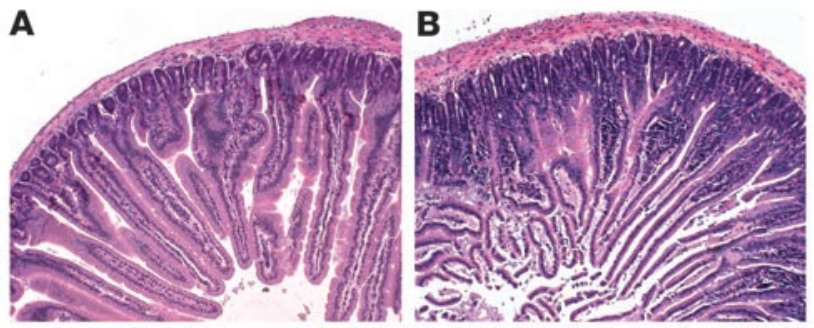

\section{Figure 6}

Histological evidence of increased small bowel inflammation. H\&Estained, formalin-fixed, paraffin-embedded, transverse sections of proximal jejunum obtained $1 \mathrm{~cm}$ from the gastroduodenal junction. (A) Representative sections from WT mice. (B) Representative sections from PXR-deficient mice. Magnification, $\times 100$.

to restrict the activity of NF- $\mathrm{KB}$ in vivo and that loss of SXR/PXR results in increased small bowel inflammation.

\section{Discussion}

The mammalian xenobiotic response is mediated primarily through the activity of 4 families of CYP monooxygenases. CYP3A4, the most abundant human CYP isoform, is the most important since it is responsible for the metabolism of more than $50 \%$ of clinically used drugs and a corresponding number of xenobiotic chemicals (17). It has long been known that expression of hepatic CYP genes can be profoundly decreased by various infectious and inflammatory stimuli, with concomitant clinical and toxicological consequences (27). Since SXR is a major regulator of CYP3A4 (16) and NF- $\mathrm{BB}$ is the central transcriptional regulator of the immune and inflammatory responses (36), we hypothesized that these pathways each inhibit the activity of the other. As shown above, NF- $\mathrm{KB}$ activation inhibits SXR activity and CYP3A4 gene expression whereas inhibition of NF- $\kappa \mathrm{B}$ activity by $\mathrm{I} \kappa \mathrm{B} \alpha \mathrm{M}$ is able to rescue repressed SXR activity and enhance SXR-mediated CYP3A4 expression. Similarly, SXR activation inhibits the activity of NF- $\mathrm{KB}$ and the expression of its target genes. The expression of NF- $\kappa \mathrm{B}$ target genes is substantially upregulated in multiple tissues, and small bowel inflammation is significantly increased in PXR knockout mice.

Although it has previously been reported that RIF binds to and activates the GR, potentially leading to glucocorticoid-like immunosuppressive effects (10), we confirmed that RIF had no effect on GR activity, which is consistent with the results from other groups $(11,12)$. Instead, both RIF and the GR antagonist RU486 activated SXR and inhibited NF- $\mathrm{KB}$ activity. This reveals the likely mechanism underlying the immunosuppressive effects of RIF and also provides an alternative explanation for the dual antiglucocorticoid and immunosuppressive effects of RU486. RIF is widely used in the treatment of all diseases caused by Mycobacterium tuberculosis and its relatives (1). Although the clinical benefit in this setting is clearly documented, our studies suggest that equally effective antimycobacterial compounds that do not engage SXR may have greater efficacy. Such compounds would not be expected to induce SXR-mediated interference with NF-KB action or SXR-regulated drug metabolic enzymes. With the increasing incidence of tuberculosis infections in the susceptible HIV-infected population and the emergence of highly resistant bacteria, a growing number of patients are being treated with RIF (51). Therefore, our studies may have direct clinical consequences for treatment of tuberculosis and other infections in immunocompromised patients, including those with AIDS.

In addition to the liver and intestine, SXR is also expressed at low levels in other tissues, including kidney and lung (42), bone (43), normal and neoplastic breast tissue $(52,53)$, and peripheral blood mononuclear cells $(54,55)$. It is currently unclear what role SXR is playing in those tissues. NF- $\mathrm{KB}$, on the other hand, is ubiquitously expressed and may also repress SXR activity in those tissues. Since

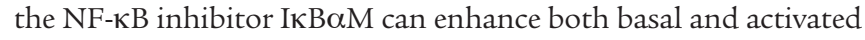
SXR activity and SXR-mediated CYP3A4 gene expression (Figure 3B

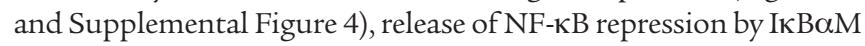
may provide a way to reveal SXR's novel functions in those tissues.

Crosstalk between NF- $\mathrm{KB}$ and the aryl hydrocarbon receptor (AhR) that prevented AhR from activating the CYP1A1 genes was previously demonstrated (56). Other studies showed that injection of LPS into mouse liver led to a reduction in CYP3A and CYP2B expression that was associated with a marked reduction of PXR and CAR mRNA levels (57). In contrast, we showed that downregulation of CYP3A4 mRNA expression in human primary hepatocytes or intestinal cells was not associated with changes in SXR mRNA expression. This is consistent with a recent report that shows that SXR gene expression is unaffected by TNF- $\alpha$ in intestinal cells (50). Another report showed that TNF- $\alpha$ was able to significantly reduce mRNA for nuclear receptor coactivators SRC-1 and SRC-2, thus limiting transactivation mediated by the progesterone receptor (58). These results show that there is unlikely to be a single common mechanism for the downregulation of CYP genes by inflammatory mediators. The mutually inhibitory interaction between SXR and NF- $\mathrm{KB}$ provides an important new mechanism for downregulation of CYP3A4 by inflammatory mediators that is important for the response of organisms to physiological and pathophysiological signals.

It has recently been reported that SXR can also negatively regulate other signaling pathways. For example, SXR normally represses CAR-mediated expression of genes involved in bilirubin clearance. These genes are upregulated in PXR knockout mice (59). Our study has revealed that SXR can also repress NF- $\mathrm{KB}$-mediated gene activation. This repression is SXR dependent, and its ligands further enhance the repression. Similarly to some CAR target genes, $\mathrm{NF}-\kappa \mathrm{B}$ target genes, particularly proinflammatory cytokines, are also upregulated in PXR knockout mice. Although transrepression by nuclear receptors and crosstalk between nuclear receptors and other signaling pathways have been extensively studied, the molecular mechanisms are still far from being completely understood (32). For instance, many plausible models have been proposed for the crosstalk between NF-кB and GR, and each of them is supported by experimental evidence. However, the models are mutually inconsistent in many ways, and the topic remains highly controversial $(33,34)$. Moreover, it was found recently that transrepression of NF- $\kappa \mathrm{B}$ target genes by another nuclear receptor - PPAR $\gamma-$ is mediated by SUMOylation of PPAR $\gamma$ (60). Interestingly, the SXR ligand-binding domain also contains a consensus SUMOylation site. Further investigation will reveal whether SUMOylation of SXR mediates transrepression of NF- $\mathrm{KB}$ signaling pathway.

As a key regulator of inflammation, activated NF- $\mathrm{KB}$ is frequently detected in various inflammatory diseases and tumors. We observed increased proinflammatory gene expression in PXR knockout mice, which is likely due to the loss of repression of NF-кB by PXR in vivo. Furthermore, the small bowel of PXR 
knockout mice exhibits a prominent, increased chronic inflammatory infiltrate. This histological pattern of a mucosal mononuclear inflammatory infiltrate is reminiscent of that seen in humans with IBDs such as celiac disease $(61,62)$. Although the hallmark villous atrophy was not seen in these specimens, variants of celiac disease with villous hypertrophy or modest atrophy have been described (Marsh I, Marsh II, and Marsh IIIa subtypes) (62). Interestingly, current thinking on the pathophysiology of celiac disease relies heavily on dysregulation of the enteric immune activity $(62,63)$. Elements reflective of other specific allergic or IBD diagnoses were also absent. It remains to be seen if specific dietary, toxic, or infectious challenges will manifest additional histological changes in the small bowel and other tissues. Recent work has shown that NF-KB plays key roles in linking inflammation to various kinds of tumor development, including colon and liver cancer (64-66). Therefore, this prominent inflammatory infiltrate that is present without specific challenge suggests that these animals may develop inflammation-associated neoplasms, either lymphoreticular or epithelial, with increasing age $(67,68)$. The anatomically limited inflammation argues for a localized mucosal effect of the loss of PXR expression in a tissue that normally expresses significant levels of PXR. The increased small bowel inflammation in PXR knockout mice is consistent with 2 recent studies that correlated loss of SXR/PXR expression or activity in the gut with the pathophysiology of IBDs $(49,50)$. The presence of increased chronic inflammation in the small bowel of PXR knockout mice also supports the involvement of SXR/PXR in regulating proinflammatory gene expression through repression of NF- $\mathrm{kB}$ activity. On the other hand, inhibition or disruption of the NF-kB pathway can effectively attenuate inflammatory response and formation of inflammation-associated tumors $(64,66)$. This makes NF-KB inhibition a proposed therapeutic strategy in the treatment of inflammation and cancer. Therefore, the crosstalk between NF-KB and SXR may provide a connection between xenobiotic metabolism and inflammatory disease and could lead to new insights into treatment strategies for inflammation and inflammation-associated cancer. The mutually inhibitory crosstalk between SXR and NF-KB widens the pharmacological implications of SXR action beyond drug interactions and the xenobiotic response and establishes an important relationship between xenobiotic metabolism and inflammation or immune response.

\section{Methods}

Reagents and plasmids. RIF, DEX, RU486, clotrimazole, recombinant human TNF- $\alpha$, and TPA were purchased from Sigma-Aldrich. Anti-SXR antibody and anti-NF-KB p65 antibodies were purchased from Santa Cruz Biotechnology Inc. SXR, GR, and CMX- $\beta$ gal expression vectors have been previously described. IкB $\alpha \mathrm{M}$, which contains a serine to alanine mutation in amino acids 32 and 36 and p65 expression vectors, was kindly provided by X. Lin (University of Texas M.D. Anderson Cancer Center, Houston, Texas, USA). SXR-dependent reporter (XREM-LUC) has been described (69), and NF-KBdependent reporter (NF-кBx3-LUC) and COX-2 promoter (COX-2-LUC) were kindly provided by C. Glass (UCSD, La Jolla, California, USA) and P. Tontonoz (UCLA, Los Angeles, California, USA) (70).

Cell culture and transfections. The human hepatic cell line HepG2, intestinal epithelial cell line LS180, and mouse macrophage cell line RAW264.7 were obtained from ATCC and cultured in DMEM containing 10\% FBS at $37^{\circ} \mathrm{C}$ in $5 \% \mathrm{CO}_{2}$. The cells were seeded into 6-well plates and grown in DMEM-10\% FBS until 70-80\% confluence. Twenty-four hours before treatment, the medium was replaced with DMEM containing $10 \%$ resin- charcoal-stripped FBS. Immediately before treatment, the medium was removed; the cells were washed once with PBS and then treated with compounds or DMSO vehicle for various times as indicated in Results. Human primary hepatocytes were obtained from the Liver Tissue Procurement and Distribution System (LTPADS) as attached cells in 6-well plates. Mouse primary hepatocytes were isolated from WT and PXR knockout mice as described (71). The hepatocytes were maintained in hepatocyte medium (Sigma-Aldrich) for at least 24 hours before treatment.

Transfection assays and LUC and $\beta$-gal were performed as described (69). Cells were seeded into 12 -well plates overnight and transiently transfected by FuGene 6 (Roche Diagnostics). Twenty-four hours after transfection, the cells were treated as indicated in Figures 1 and 2 . The cells were lysed 24 hours after treatment, and $\beta$-gal and luciferase assays were performed as described. Reporter gene activity was normalized to the $\beta$-gal transfection controls and the results expressed as normalized RLU per OD $\beta$-gal per minute to facilitate comparisons between plates. Each data point represents the average of triplicate experiments \pm SEM and was replicated in independent experiments.

RNA isolation and QRT-PCR analysis. Total RNA was isolated from LS180 cells, primary hepatocytes, and mouse and human tissues using TRIzOL Reagent (Invitrogen) according to the manufacturer-supplied protocol. The collection and use of human tissue for research was approved by the University of Washington Human Subjects Review Board. Samples of human livers from white donors were selected from the University of Washington School of Pharmacy Human Tissue Bank. QRT-PCR was performed using gene specific primers and the SYBR Green RTPCR Kit (Applied Biosystems) in a DNA Engine Opticon Fluorescence Detection System (MJ Research). All samples were quantified using the comparative $\mathrm{Ct}$ method for relative quantification of gene expression, normalized to GAPDH (69). The following primer sets were used in this study: IL-2 (5'-CAACTCCTGTCTTGCATTGC-3' and 5'-GCTCCAGTTGTAGCTGTGTT- $\left.3^{\prime}\right)$; TNF- $\alpha$ (5'-AACCTCCTCTCTGCCATCAA-3' and $5^{\prime}$-GGAAGACCCCTCCCAGATAG-3'); IкB $\alpha$ (5'-GGCTGAAGAAGGAGCGGCTA- $3^{\prime}$ and $5^{\prime}$-CCATCTGCTCGTACTCCTCG-3'); COX-2 (5'-TGAGCATCTACGGTTTGCTG-3' and 5' -TGCTTGTCTGGAACAACTGC-3'); CYP3A4 (5'-GGCTTCATCCAATGGACTGCATAAAT-3' and $5^{\prime}$-TCCCAAGTATAACACTCTACACAGACAA- $\left.3^{\prime}\right)$; SXR (5'-TGGGTGACACCTCCGAGA-3' ${ }^{\prime}$ and $5^{\prime}$-TAGGGAGACAGGCCAGCA-3'); GAPDH (5'-GGCCTCCAAGGAGTAAGACC-3' and $5^{\prime}$-AGGGGAGATTCAGTGTGGTG-3'); mouse CYP3A11 (5'-CAGCTTGGTGCTCCTCTACC-3' and 5'-TCAAACAACCCCCATGTTTT-3'); mouse IкB $\alpha$ (5'-TGAAGGACGAGGAGTACGAGC- $3^{\prime}$ and $5^{\prime}$-TTCGTGGATGATTGCCAAGTG-3'); mouse TNF- $\alpha\left(5^{\prime}\right.$-CCCTCACACTCAGATCATCTTCT- ${ }^{\prime}$ and $5^{\prime}$-GCTACGACGTGGGCTACAG-3'); mouse COX-2 (5'-TGAGCAACTATTCCAAACCAGC-3' and 5'-GCACGTAGTCTTCGATCACTATC-3'); mouse IL-2 (5'-ATGTACAGCATGCAGCTCGC- $3^{\prime}$ and $5^{\prime}$-AAGTGGGTGCGCTGTTGACA-3'); mouse IL-6 (5'-TAGTCCTTCCTACCCCAATTTCC-3' and 5'-TTGGTCCTTAGCCACTCCTTC-3'); mouse GAPDH (5'-AACTTTGGCATTGTGGAAGG-3' and $5^{\prime}$-GGATGCAGGGATGATGTTCT- $3^{\prime}$ ); mouse IL-15 (5'-ACATCCATCTCGTGCTACTTGT- ${ }^{\prime}$ and $5^{\prime}$-GCCTCTGTTTTAGGGAGACCT- $\left.3^{\prime}\right)$; mouse IL- $1 \alpha\left(5^{\prime}\right.$-GCACCTTACACCTACCAGAGT-3' and $5^{\prime}$-TGCAGGTCATTTAACCAAGTGG-3'); mouse IL-1 $\beta$ (5'-GCAACTGTTCCTGAACTCAACT- ${ }^{\prime}$ and $5^{\prime}$-ATCTTTTGGGGTCCGTCAACT-3'); and mouse ICAM-1 (5'-GGCATTGTTCTCTAATGTCTCCG-3' and $5^{\prime}$-GCTCCAGGTATATCCGAGCTTC-3').

Animals and histological evaluation. $\mathrm{PXR}^{-1-}$ and $\mathrm{C} 57 \mathrm{BL} 6 / \mathrm{J}$ (WT) mice were maintained on standard chow. Ten-week-old male C57BL6/J and PXR-/mice received intraperitoneal injections of either the PXR ligand PCN (50 $\mathrm{mg} / \mathrm{kg}$ ) or DMSO control solution for 3 consecutive days. On the third day, mice were euthanized and tissues were harvested for further analysis. 
For histological evaluation, multiple tissues from $\mathrm{PXR}^{-1-}$ and WT mice were fixed in formalin, embedded in paraffin, sectioned, and stained with H\&E. Animal care and use was in accordance with applicable standards and approved by the Institutional Animal Care and Use Committees at the University of California, Irvine, and the City of Hope National Medical Center.

Statistics. Differences between 2 groups were analyzed using 2-sample, 2-tailed Student's $t$ test. A $P$ value of less than 0.05 was considered to be significant. All data are presented in the text and figures as the mean \pm SEM.

\section{Acknowledgments}

We thank R. Kaigh and members of the Blumberg laboratory for critically reading the manuscript; A. Garcia for technical support; T. Moore for assistance with mouse dissection; Y. Xu for human tissue sample preparation; and X. Lin, D. Chakravarti, L.P. Freedman, and C. Glass for plasmids. This work was supported by grants from the NIH (GM-60572), US Environmental Protection Agency (STAR R830686), and the Department of Defense (DAMD17-02-
1-0323) to B. Blumberg, and the NIH (AT00886) to B.M. Forman and (GM063666) to K.E. Thummel. Normal human hepatocytes were obtained through the Liver Tissue Procurement and Distribution System (LTPADS), funded by NIH contract N01-DK-9-2310. A. Sadatrafiei was the recipient of a University of California, Irvine, Undergraduate Research Opportunity grant.

Received for publication July 14, 2005, and accepted in revised form May 23, 2006.

Address correspondence to: Bruce Blumberg, 5205 McGaugh Hall, Department of Developmental and Cell Biology, University of California, Irvine, Irvine, California 92697-2300, USA. Phone: (949) 824-8573; Fax: (949) 824-4709; E-mail: blumberg@uci.edu.

Changcheng Zhou's present address is: Department of Pharmaceutics, University of Washington, Seattle, Washington, USA.
1. Mitchison, D.A. 1992. The Garrod Lecture. Understanding the chemotherapy of tuberculosis-current problems. J. Antimicrob. Chemother. 29:477-493.

2. Sande, M.A. 1983. The use of rifampin in the treatment of nontuberculous infections: an overview. Rev. Infect. Dis. 5(Suppl. 3):S399-S401.

3. Mandell, G.L., Bennett, J.E., and Dolin, R. 2004 Principles and practice of infectious diseases. 6 th edition. Elsevier Churchill Livingstone. New York, New York, USA. 3661 pp.

4. Niemi, M., Backman, J.T., Fromm, M.F., Neuvonen, P.J., and Kivisto, K.T. 2003. Pharmacokinetic interactions with rifampicin: clinical relevance. Clin. Pharmacokinet. 42:819-850.

5. Grosset, J., and Leventis, S. 1983. Adverse effects of rifampin. Rev. Infect. Dis. 5(Suppl. 3):S440-S450.

6. Ibrahim, M.S., Maged, Z.A., Haron, A., Khalil, R.Y., and Attallah, A.M. 1987. Antibiotics and immunity: effects of antibiotics on natural killer, antibody dependent cell-mediated cytotoxicity and antibody production. Chemioterapia. 6:426-430.

7. Paunescu, E. 1970 . In vivo and in vitro suppression of humoral and cellular immunological response by rifampicin. Nature. 228:1188-1190.

8. Litwin, A., Brooks, S.M., and Claes, F. 1974. A pilot study concerning the early immunosuppressive effects of rifampin in man. Chest. 65:548-551.

9. Nessi, R., Pallanza, R., and Fowst, G. 1974. Rifampicin and immunosuppression. Arzneimittelforschung. 24:832-836.

10. Calleja, C., Pascussi, J.M., Mani, J.C., Maurel, P., and Vilarem, M.J. 1998. The antibiotic rifampicin is a nonsteroidal ligand and activator of the human glucocorticoid receptor. Nat. Med. 4:92-96.

11. Ray, D.W., Lovering, A.M., Davis, J.R., and White, A. 1998. Rifampicin: a glucocorticoid receptor ligand? Nat. Med. 4:1090-1091.

12. Jaffuel, D., et al. 1999. Rifampicin is not an activator of the glucocorticoid receptor in A549 human alveolar cells. Mol. Pharmacol. 55:841-846.

13. Blumberg, B., et al. 1998. SXR, a novel steroid and xenobiotic-sensing nuclear receptor. Genes Dev. 12:3195-3205.

14. Kliewer, S.A., et al. 1998. An orphan nuclear receptor activated by pregnanes defines a novel steroid signaling pathway. Cell. 92:73-82.

15. Bertilsson, G., et al. 1998. Identification of a human nuclear receptor defines a new signaling pathway for CYP3A induction. Proc. Natl. Acad. Sci. U. S. A. 95:12208-12213.

16. Kliewer, S.A., Goodwin, B., and Willson, T.M. 2002. The nuclear pregnane $\mathrm{X}$ receptor: a key regulator of xenobiotic metabolism. Endocr. Rev. 23:687-702.

17. Guengerich, F.P. 1999. Cytochrome P-450 3A4: regulation and role in drug metabolism. Annu. Rev.
Pharmacol. Toxicol. 39:1-17.

18. Dussault, I., and Forman, B.M. 2002. The nuclear receptor PXR: a master regulator of "homeland" defense. Crit. Rev. Eukaryot. Gene Expr. 12:53-64.

19. Raucy, J.L. 2003. Regulation of CYP3A4 expression in human hepatocytes by pharmaceuticals and natural products. Drug Metab. Dispos. 31:533-539.

20. Xie, W., and Evans, R.M. 2002. Pharmaceutical use of mouse models humanized for the xenobiotic receptor. Drug Discov. Today. 7:509-515.

21. Xie, W., et al. 2000. Humanized xenobiotic response in mice expressing nuclear receptor SXR. Nature. 406:435-439.

22. Sorrell, T.C., Forbes, I.J., Burness, F.R., and Rischbieth, R.H. 1971. Depression of immunological function in patients treated with phenytoin sodium (sodium diphenylhydantoin). Lancet. 2:1233-1235.

23. Sorrell, T.C., and Forbes, I.J. 1975. Depression of immune competence by phenytoin and carbamazepine. Studies in vivo and in vitro. Clin. Exp. Immunol. 20:273-285.

24. Badawy, A.H., Shalaby, S.A., and Abdel Aal, S.F. 1991. Hydantoin immunosuppression clinical study. J. Egypt. Soc. Parasitol. 21:257-262.

25. Van Voorhis, B.J., Anderson, D.J., and Hill, J.A. 1989. The effects of RU 486 on immune function and steroid-induced immunosuppression in vitro. J. Clin. Endocrinol. Metab. 69:1195-1199.

26. Antonakis, N., et al. 1991. The antiglucocorticoid RU486 downregulates the expression of interleukin-2 receptors in normal human lymphocytes. J. Steroid Biochem. Mol. Biol. 39:929-935.

27. Morgan, E.T. 1997. Regulation of cytochromes P450 during inflammation and infection. Drug Metab. Rev. 29:1129-1188.

28. Morgan, E.T. 2001. Regulation of cytochrome p450 by inflammatory mediators: why and how? Drug Metab. Dispos. 29:207-212.

29. Riddick, D.S., et al. 2004. Transcriptional suppression of cytochrome P450 genes by endogenous and exogenous chemicals. Drug Metab. Dispos. 32:367-375.

30. Abdel-Razzak, Z., et al. 1993. Cytokines downregulate expression of major cytochrome P-450 enzymes in adult human hepatocytes in primary culture. Mol. Pharmacol. 44:707-715.

31. Ogawa, S., et al. 2005. Molecular determinants of crosstalk between nuclear receptors and toll-like receptors. Cell. 122:707-721.

32. De Bosscher, K., Vanden Berghe, W., and Haegeman, G. 2003. The interplay between the glucocorticoid receptor and nuclear factor-kappaB or activator protein-1: molecular mechanisms for gene repression. Endocr. Rev. 24:488-522.
33. Almawi, W.Y., and Melemedjian, O.K. 2002. Negative regulation of nuclear factor-kappaB activation and function by glucocorticoids. J. Mol. Endocrinol. 28:69-78.

34. McKay, L.I., and Cidlowski, J.A. 1999. Molecular control of immune/inflammatory responses: interactions between nuclear factor-kappa B and steroid receptor-signaling pathways. Endocr. Rev. 20:435-459.

35. Baeuerle, P.A., and Baltimore, D. 1996. NF-kappa B: ten years after. Cell. 87:13-20.

36. Ghosh, S., May, M.J., and Kopp, E.B. 1998. NF-kappa $B$ and Rel proteins: evolutionarily conserved mediators of immune responses. Annu. Rev. Immunol. 16:225-260.

37. Scheinfeld, N. 2003. Phenytoin in cutaneous medicine: its uses, mechanisms and side effects. Dermatol. Online J. 9:6.

38. Wang, H., et al. 2004. Human constitutive androstane receptor mediates induction of CYP2B6 gene expression by phenytoin. J. Biol. Chem. 279:29295-29301.

39. Faucette, S.R., et al. 2006. Differential regulation of hepatic Cyp2 26 and Cyp3a4 genes by constitutive androstane receptor but not pregnane $\mathrm{X}$ receptor. J. Pharmacol. Exp. Ther. 317:1200-1209.

40. Orisakwe, O.E., Akunyili, D.N., Agbasi, P.U., and Ezejiofor, N.A. 2004. Some plasma and saliva pharmacokinetics parameters of rifampicin in the presence of pefloxacin. Am. J. Ther. 11:283-287.

41. Geleziunas, R., et al. 1998. Human T-cell leukemia virus type 1 tax induction of NF-kappaB involves activation of the IkappaB kinase alpha (IKKalpha) and IKKbeta cellular kinases. Mol. Cell. Biol. 18:5157-5165.

42. Miki, Y., Suzuki, T., Tazawa, C., Blumberg, B., and Sasano, H. 2005. Steroid and xenobiotic receptor (SXR), cytochrome P450 3A4 and multidrug resistance gene 1 in human adult and fetal tissues. Mol. Cell. Endocrinol. 231:75-85.

43. Tabb, M.M., et al. 2003. Vitamin K2 regulation of bone homeostasis is mediated by the steroid and xenobiotic receptor SXR. J. Biol. Chem. 278:43919-43927.

44. Ziglam, H.M., Daniels, I., and Finch, R.G. 2004. Immunomodulating activity of rifampicin. J. Chemother. 16:357-361.

45. Sonoda, J., et al. 2005. Pregnane X receptor prevents hepatorenal toxicity from cholesterol metabolites. Proc. Natl. Acad. Sci. U. S. A. 102:2198-2203.

46. Wolf, K.K., et al. 2005. Role of the nuclear receptor pregnane $\mathrm{X}$ receptor in acetaminophen hepatotoxicity. Drug Metab. Dispos. 33:1827-1836.

47. Stedman, C.A., et al. 2005. Nuclear receptors constitutive androstane receptor and pregnane $\mathrm{X}$ 
receptor ameliorate cholestatic liver injury. Proc. Natl. Acad. Sci. U. S. A. 102:2063-2068.

48. Maggio-Price, L., et al. 2002. Helicobacter bilis infection accelerates and $\mathrm{H}$. hepaticus infection delays the development of colitis in multiple drug resistance-deficient (mdr1a-/-) mice. Am. J. Pathol. 160:739-751.

49. Dring, M.M., et al. 2006. The pregnane X receptor locus is associated with susceptibility to inflammatory bowel disease. Gastroenterology. 130:341-348.

50. Langmann, T., et al. 2004. Loss of detoxification in inflammatory bowel disease: dysregulation of pregnane X receptor target genes. Gastroenterology. 127:26-40.

51. Bloom, B.R., and Murray, C.J. 1992. Tuberculosis: commentary on a reemergent killer. Science. 257:1055-1064.

52. Dotzlaw, H., Leygue, E., Watson, P., and Murphy, L.C. 1999. The human orphan receptor PXR messenger RNA is expressed in both normal and neoplastic breast tissue. Clin. Cancer Res. 5:2103-2107.

53. Miki, Y., et al. 2006. Expression of the steroid and xenobiotic receptor and its possible target gene, organic anion transporting polypeptide-A, in human breast carcinoma. Cancer Res. 66:535-542.

54. Albermann, N., et al. 2005. Expression of the drug transporters MDR1/ABCB1, MRP1/ABCC1, MRP2/ABCC2, BCRP/ABCG2, and PXR in peripheral blood mononuclear cells and their relationship with the expression in intestine and liver. Biochem. Pharmacol. 70:949-958.

55. Owen, A., Chandler, B., Back, D.J., and Khoo, S.H. 2004. Expression of pregnane-X-receptor transcript in peripheral blood mononuclear cells and correlation with MDR1 mRNA. Antivir. Ther. 9:819-821.

56. Ke, S., Rabson, A.B., Germino, J.F., Gallo, M.A., and Tian, Y. 2001. Mechanism of suppression of cytochrome P-450 1A1 expression by tumor necrosis factor-alpha and lipopolysaccharide. J. Biol. Chem. 276:39638-39644.

57. Beigneux, A.P., Moser, A.H., Shigenaga, J.K., Grunfeld, C., and Feingold, K.R. 2002. Reduction in cytochrome P-450 enzyme expression is associated with repression of CAR (constitutive androstane receptor) and PXR (pregnane $\mathrm{X}$ receptor) in mouse liver during the acute phase response. Biochem. Biophys. Res. Commun. 293:145-149.

58. Leite, R.S., Brown, A.G., and Strauss, J.F., 3rd. 2004 Tumor necrosis factor-alpha suppresses the expression of steroid receptor coactivator- 1 and -2 : a possible mechanism contributing to changes in steroid hormone responsiveness. FASEB J. 18:1418-1420.

59. Saini, S.P., et al. 2005. Dual role of orphan nuclear receptor pregnane $\mathrm{X}$ receptor in bilirubin detoxification in mice. Hepatology. 41:497-505.

60. Pascual, G., et al. 2005. A SUMOylation-dependent pathway mediates transrepression of inflammatory response genes by PPAR-gamma. Nature. 437:759-763.

61. Kagnoff, M.F. 2005. Overview and pathogenesis of celiac disease. Gastroenterology. 128(4 Suppl. 1): S10-S18.

62. Wahab, P.J., Meijer, J.W., Goerres, M.S., and Mulder, C.J. 2002. Coeliac disease: changing views on gluten-sensitive enteropathy. Scand. J. Gastroenterol. Suppl. 236:60-65.
63. Macdonald, T.T., and Monteleone, G. 2005. Immunity, inflammation, and allergy in the gut. Science. 307:1920-1925.

64. Greten, F.R., et al. 2004. IKKbeta links inflammation and tumorigenesis in a mouse model of colitis-associated cancer. Cell. 118:285-296.

65. Pikarsky, E., et al. 2004. NF-kappaB functions as a tumour promoter in inflammation-associated cancer. Nature. 431:461-466.

66. Karin, M., and Greten, F.R. 2005. NF-kappaB: linking inflammation and immunity to cancer development and progression. Nat. Rev. Immunol. 5:749-759.

67. Philip, M., Rowley, D.A., and Schreiber, H. 2004. Inflammation as a tumor promoter in cancer induction. Semin. Cancer Biol. 14:433-439.

68. Catassi, C., Bearzi, I., and Holmes, G.K. 2005. Association of celiac disease and intestinal lymphomas and other cancers. Gastroenterology. 128(4 Suppl. 1):S79-S86.

69. Zhou, C., Tabb, M.M., Sadatrafiei, A., Grun, F., and Blumberg, B. 2004. Tocotrienols activate the steroid and xenobiotic receptor, SXR, and selectively regulate expression of its target genes. Drug Metab. Dispos. 32:1075-1082.

70. Joseph, S.B., Castrillo, A., Laffitte, B.A., Mangelsdorf, D.J., and Tontonoz, P. 2003. Reciprocal regulation of inflammation and lipid metabolism by liver X receptors. Nat. Med. 9:213-219.

71. Dussault, I., et al. 2003. Identification of an endogenous ligand that activates pregnane $\mathrm{X}$ receptormediated sterol clearance. Proc. Natl. Acad. Sci.U. S. A. 100:833-838. 